\title{
MODEL PEMBERDAYAAN MASYARAKAT \\ DI WILAYAH PESISIR DALAM MENANGGULANGI KEMISKINAN DI KABUPATEN BUTON, SULAWESI TENGGARA
}

\author{
Manat Rahim; Madjiani Tahir; Waly Aya Rumbia \\ Fakultas Ekonomi, Universitas Haluoleo \\ Jln. H.E.A Mokodompit No. 1, Malaka Anduonohu, Kota Kendari 93232 \\ yadis_70@yahoo.co.id
}

\begin{abstract}
Poverty is a social reality characterized by underdevelopment in the social, economic, cultural, political, educational and natural factors that directly influence the inability of society, so as to be poor. The effort to reduce poverty is done by getting the community development approach through government programs i.e. PNPM-MP and strengthening unit districts management institutions. The data used were primary data obtained from the field survey with a list of questions; samples were 98 respondents. Research analysis used descriptive quantitative method and community empowerment model approach. Research shows that the family economic empowering 10 from 12 respondents or $83.33 \%$ increased in family income and did not work for 16,67\% respondents. Meanwhile, the traditional farmer empowerment productive effort 36 form 46 respondents or $78,26 \%$ succeeded to increase household income of farmers and $21,74 \%$ were not able to increase the income of farm households. Meanwhile, venture capital empowerment fishermen increased fishing activity and managed marine products with a success rate of 55\% and $45 \%$ did not succeed.
\end{abstract}

Keywords: poverty alleviation, community empowering, farmers, fishermen

\begin{abstract}
ABSTRAK
Kemiskinan merupakan merupakan realitas sosial ditandai dengan keterbelakangan banyak hal baik terkait dengan sosial, ekonomi, budaya, politik, pendidikan maupun faktor alam yang berpengaruh langsung terhadap ketidakmampuan masyarakat, sehingga menjadi miskin. Upaya penanggulangan kemiskinan dilakukan dengan pendekatan pemberdayaan masyarakat melalui program-program pemerintah antara lain PNPM-MP dan penguatan lembaga unit pengelola kecamatan. Data yang digunakan adalah data primer diperoleh dari survei lapangan dengan bantuan daftar pertanyaan. Sampel penelitian adalah 98 responden. Metode analisis yang digunakan metode deskriptif kuantitatif dan pendekatan model pemberdayaan masyarakat. Hasil penelitian menunjukkan bahwa pemberdayaan ekonomi keluarga dari 12 responden, berhasil 10 responden atau 83,33\% dalam peningkatan pendapatan keluarga dan tidak berhasil sebesar 16,67\%. Sementara itu, pemberdayaan usaha produktif petani tradisional dari 46 responden, yaitu 36 responden atau 78,26\% berhasil meningkatkan pendapatan rumah tangga petani dan $21,74 \%$ belum dapat meningkatkan pendapatan rumah tangga petani. Sementara itu, pemberdayaan modal usaha nelayan telah meningkatkan kegiatan melaut dan mengelola hasilhasil laut dengan tingkat keberhasilan sebesar $55 \%$ dan tidak berhasil 45\%.
\end{abstract}

Kata kunci: penanggulangan kemiskinan, pemberdayaan masyarakat, petani, nelayan 


\section{PENDAHULUAN}

Pemberdayaan masyarakat merupakan upaya untuk meningkatkan harkat dan martabat lapisan masyarakat yang dalam kondisi sekarang tidak mampu melepaskan diri dari perangkap kemiskinan dan keterbelakangan. Dengan kata lain memberdayakan masyarakat berarti memberikan kemampuan dan memandirikan masyarakat. Proses pemberdayaan yang menekankan pada proses memberikan kemampuan kepada masyarakat agar menjadi berdaya, mendorong atau memotivasi individu agar mempunyai kemampuan atau keberdayaan untuk menentukan pilihan hidupnya. Dalam hal ini bahwa pemberdayaan harus ditujukan pada kelompok atau lapisan masyarakat yang tertinggal. (Prijono \& Pranaka, 1996).

Pemberdayaan masyarakat tidak lain adalah upaya penanggulangan kemiskinan dan keterbelakangan. Pada gilirannya memperkuat posisi masyarakat dalam struktur ekonomi dan kekuasaan. Untuk memperkuat posisi lapisan masyarakat telah dilaksanakan secara terus-menerus oleh pemerintah pusat maupun pemerintah daerah. Pada 1993 diluncurkan kebijakan pemerintah yang tertuang dalam Inpres Nomor 5 tahun 1993, yang dikenal dengan program Inpres Desa tertinggal (IDT). Penanggulangan kemiskinan dilakukan dengan pendekatan pemberdayaan masyarakat, yakni memberikan kesempatan kepada setiap anggota masyarakat untuk dapat ikut serta dalam proses pembangunan dengan mendapatkan kesempatan yang sama dan menikmati hasil pembangunan sesuai dengan kemampuannya. Pendekatan tersebut memperoleh penguatan dalam Rancanangan Pembangunan jangka Menengah (RPJM) dan Propenas 2001-2004, yaitu upaya penanggulangan kemiskinan dilakukan dijakan dan program dengan pendekatan bahwa masyarakat memperoleh ruang untuk menentukan pilihan yang paling sesuai bagi kemajuan diri mereka masing-masing. Menurut pendekatan ini, setiap upaya pembangunan perlu diarahkan pada penciptaan suatu lingkungan yang memungkinkan masyarakat untuk menikmati kehidupan yang lebih baik sekaligus memperluas pilihan yang dapat dilakukan oleh setiap anggota masyarakat.

Pemberdayaan masyarakat diperlukan upaya untuk memadukan berbagai kebijaksanaan dan program yang tersebar di berbagai sektor dan wilayah dengan tetap memerhatikan tantangan modal potensi yang ada pada setiap orang dan setiap wilayah. Kartasasmita (1996), pemberdayaan penduduk miskin dengan kebijakan penanggulangannya dilaksanakan melalui tiga arah kebijakan. Kebijaksanaan tidak langsung diarahkan kepada penciptaan kondisi yang menjamin setiap upaya penanggulangan kemiskinanan. Kebijkasanaan langsung yang ditujukan kepada golongan masyarakat berpenghasilan rendah. Kebijaksanaan khusus yang dimaksudkan untuk mempersiapkan masyarakat miskin dan aparat yang bertanggung jawab langsung terhadap kelancaran program dan sekaligus memacu dan memperluas upaya untuk penenggulngan kemiskinan.

Model pemberdayaan penduduk miskin dengan pendekatan yang telah dilakukan oleh pemerintah di antaranya program Inpres Desa Tertinggal (IDT), Program Pengembangan Kecamatan (PPK) dan Program Pengelolaan Berbasis Masyarakat COREMAP I dan II khususnya bagi masyarakat pesisir dan kepulauan. Dalam rangka mewujudkan masyarakat yang memiliki daya dan kemampuan untuk meningkatkan kualitas sosial ekonomi secara mandiri dan berkesinambungan, maka model pemberdayaan masyarakat dengan program PNPM-MP yang bertujuan untuk mengembangkan ekonomi produktif masyarakat.

Kabupaten Buton dengan luas wilayah 2.648,08 $\mathrm{km}^{2}$, berpenduduk 284.627 jiwa, dan secara administrasi terdiri dua puluh empat kecamatan. Pertumbuhan ekonomi Kabupaten Buton berdasarkan harga konstan tahun 2000 yaitu tahun 2007 sebesar 6,15 persen meningkat menajadi 6,87 persen pada 2012. Sementara pertumbuhan PDRB per kapita Kabupaten Buton mengalami peningkatan yaitu tahun 2007 PDRB per kapita sebesar Rp 4.816,299,47 menjadi Rp 6.827.572,29 atau meningkat 16,69 persen pada 2012. Jumlah penduduk miskin di Kabupaten Buton sebanyak 67,900 jiwa atau 22,98 
persen lebih tinggi jika dibandingkan dengan Sulawesi Tenggara 19,58 persen. Sementara keluarga atau jumlah rumah tangga yang tergolong miskin berjumlah 41.197 rumah tangga (BPS, 2012).

Secara umum keluarga miskin Kabupaten Buton adalah mereka tidak mempunyai faktor produksi seperti tanah, modal, ataupun keterampilan, sehingga kemampuan untuk memperoleh pendapatan menjadi terbatas. Oleh karena itu sangat potensial menjadi kantong-kantong pemukiman penduduk miskin. Kemiskinan di wilayah pesisir Kecamatan Sampolawa, Kecamatan Wabula, dan Kecamatan Mawasangka termasuk wilayah yang sebagian besar penduduknya bermata pencaharian nelayan tardisional dan petani ladang berpindah- pindah. Pada gilirannya kehidupan ekonomi dan sosial rendah. Hal ini dapat menjadi lahan subur bagi timbulnya kerawanan-kerawanan di bidang kehidupan yang lain.

Kemiskinan dan tekanan sosial ekonomi yang dihadapi oleh rumah tangga berakar dari faktorfaktor kompleks yang terkait, antara lain pekerjaan utama sebagai nelayan tradisional, tidak memiliki faktor produksi kecuali tenaga kerja, buruh bangunan, dan pekerjaan serabutan. Berdasarkan informasi tersebut, maka penelitian ini difokuskan pada topik model pemberdayaan masyarakat dalam menanggulangi kemiskinan. Rumusan masalah dalam penelitian ini adalah bagaimana model pemberdayaan masyarakat di Kabupaten Buton, Provinsi Sulawesi Tenggara. Berangkat dari uraian latar belakang dan rumusan masalah tersebut, maka penelitian ini bertujuan untuk menganalisis pemberdayaan masyarakat di Kabupaten Buton.

\section{Kajian Teori}

\section{Konsep Pemberdayaan Masyarakat}

Pemberdayaan muncul sebagai strategi dalam paradigma pembangunan yang berpusat pada manusia (people cantered development). Konsep ini muncul dari dua yakni antara kegagalan dan harapan. Kegagalan yang di maksdudkan adalah gagalnya model pembangunan ekonomi dalam menanggulangi kamiskinan dan lingkungan yang berkelanjutan. Sedangkan harapan muncul karena adanya alternatif pembangunan yang mengutamakan nilai-nilai demokrasi, persamaan gender, persamaan antara generasi, dan pertumbuhan ekonomi yang memadai.

Konsep pemberdayaan pada awalnya muncul sebagai kritik terhadap paradigma pembangunan yang menepatkan negara terlalu domino dalam melaksakan pembangunan. Posisi sentral negara terlihat dari mulai perencanaan sampai pada tahap pelaksanaan dan evaluasi. Konsep pemberdayaan ini berasumsi bahwa pembangunan akan berjalan lancar apabila masyarakat di beri kesempatan atau berhak mengelolah sumber daya yang ada untuk kepetingan masyarakat itu sendiri. Memberdayakan masyaraka yang dalam kondisi sekarang tidak mampu melepaskan masyarakat adalah upaya untuk meningkatkan harkat dan martabat lapisan masyarakat yang dalam kondisi sekarang tidak mampu melepaskan diri dari perengkap kemiskinan dan keterbelakangan. Dengan kata lain memberdayakan adalah meningkatkan kemampuan dan meningkatakan kemandirian masyarakat.

Pemberdayaan (empowerment) menurut Kartasasmita (1996) berdasarkan makna katanya diartikan sebagai kekuatan yang berasal dari dalam, yang dapat diperkuat dengan unsur-unsur dari luar. Cook dan Macaulay (1997) mengemukakan bahwa pemberdayaan lebih memandang masyarakat sebagai subjek yang dapat melakukan perubahan dengan cara membebaskan seseorang dari kendala dan memberi orang atau masyarakat dengan kebebasan untuk bertanggung jawab terhadap ide-ide, keputusan, dan tindakannya. Di sisi lain pemberdayaan masyarakat adalah upaya membangun daya dengan cara mendorong dan membangkitkan kesadaran akan potensi yang dimiliki serta mengembangkannya. Pemberdayaan masyarakat dalam hal ini merupakan strategi yang sangat potensial dalam rangka meningkatkan ekonomi dan sosial. Hasil penelitian Bahruddin (2004) 
melaporkan bahwa pemberdayaan masyarakat di Kecamatan Tiris Probolinggo dengan program pemberian modal usaha berpengaruh terhadap pengentasan kemiskinan. Selanjutnya program pemberdayaan masyarakat dengan pemberian modal usaha dan keterampilan dapat mendorong usahausaha produktif guna meningkatkan pendapatan. Berdasarkan hasil penelitian Abibu (2007), dilaporkan bahwa pemberdayaan perempuan melalui penguatan ekonomi produktif dengan program pemberian modal usaha di Kabupaten Konawe dapat meningkatkan pendapatan rumah tangga. Lebih jauh Huda (2005) melaporkan bahwa pemberdayaan dengan pemberian kredit mikro terhadap pendapatan masyarakat pedesaan melalui lembaga simpan pinjam berbasis masyarakat dari program pemberdayan masyarakat (CERD) di Kecamatan Aluh-Aluh Kabupaten Banjar dapat meningkatkan pendapatan masyarakat.

\section{Konsep Kemiskinan}

Pada dasarnya kemiskinan identik dengan taraf hidup yang rendah atau dapat diartikan sebagai suatu keadaan dimana kehidupan penduduk diwarnai oleh serba kekurangan akan kebutuhan pokok. Seperti dikemukakan Widodo dalam Kastasasmita (1996) bahwa konsep kebutuhan dasar selalu dikaitkan dengan kemiskinan karena masalah kemiskinan merupakan obsesi bangsa dan persoalan mendasar yang harus ditangani. Penduduk miskin umumnya tidak berpenghasilan cukup, bahkan tidak berpenghasilan sama sekali. Penduduk miskin umumnya lemah dalam kemampuan berusaha, dan terbatas aksesnya pada kegiatan ekonomi, sehingga tertinggal dari masyarakat lainnya.

Nasution (1996) mengemukakan bahwa pada hakikatnya seseorang digolongkan miskin jika keadaannya menyebabkan dia tidak mampu menaati tata nilai dan norma-norma yang dijunjung tinggi oleh masyarakatnya. Pendapat ini mengindikasikan bahwa kemiskinan dapat diartikan sebagai suatu keadaan, yang seseorang, keluarga, atau anggota masyarakat tidak mempunyai kemampuan untuk memenuhi kebutuhan hidupnya secara wajar sebagaimana anggota masyarakat lain pada umumnya.

Prayitno dan Santosa (1996) mengatakan bahwa ada tiga dimensi (aspek atau segi) kemiskinan. Pertama, kemiskinan multidimensional, artinya karena kebutuhan manusia itu bermacammacam, maka kemiskinan juga memiliki banyak aspek. Dilihat dari kebijakan umum kemiskinan meliputi aspek primer yang berupa miskin akan aset-aset, organisasi sosial politik dan pengetahuan serta keterampilan; dan aspek sekunder yang berupa miskin akan jaringan sosial, sumber-sumber keuangan, dan informasi. Dimensi-dimensi kemiskinan tersebut memanifestasikan dirinya dalam bentuk kekurangan gizi, air, dan perumahan yang tidak sehat, dan perawatan kesehatan yang kurang baik serta pendidikan yang juga kurang baik. Kedua, aspek-aspek kemiskinan tadi saling berkaitan, baik secara langsung maupun tidak langsung. Hal ini berarti bahwa kemajuan atau kemunduran pada salah satu aspek dapat memengaruhi kemajuan atau kemunduran pada aspek lainnya. Ketiga, bahwa yang miskin adalah manusianya, baik secara individual maupun kolektif. Sering terdengar perkataan kemiskinan pedesaan (rural poverty), kemiskinan perkotaan (urban poverty), dan sebagainya. Ini bukan berarti desa atau kota yang mengalami kemiskinan, melainkan orang-orang atau penduduk atau juga manusianya yang menderita miskin.

Penjelasan tersebut menunjukkan bahwa konsep kemiskinan mempunyai dimensi yang luas dan kompleks. Menurut Usman dalam Prijono dan Pranarka (1996) paling tidak ada tiga macam konsep kemiskinan: kemiskinan absolut, relatif, dan subjektif. Sedangkan Nasution (1996) menggolongkan kemiskinan ke dalam kemiskinan: alamiah dan struktural atau kemiskinan buatan (man made poverty).

Konsep kemiskinan dapat pula dibagi atas kemiskinan material dan non-material. Kemiskinan material diukur berdasarkan penghasilan, dan kemiskinan non-material ditandai oleh tidak adanya kebebasan berpolitik, bergerak, berpendapat, dan sebagainya (White dalam Sitorus, dkk., 1996). Konsep kemiskinan ini sama dengan pendapat Soetrisno (1996) bahwa di Indonesia ada 2 kemiskinan, yakni kemiskinan ekonomi dan politik. 
Kartasasmita (1996) menjelaskan konsep kemiskinan dari tiga sudut pandang. Pertama, dari segi pola waktunya kemiskinan dibedakan atas: persistent poverty, cyclical poverty, seasonal poverty, dan accidental poverty. Kedua, dari segi penyebabnya kemiskinan dibedakan atas kemiskinan kultural dan struktural. Ketiga, dari segi pengukurannya kemiskinan dibedakan atas: absolut dan relatif. Kemiskinan absolut ditandai oleh lebih rendahnya tingkat pendapatan daripada garis kemiskinan. Kemiskinan relatif ditandai oleh adanya kelompok yang miskin dan tidak miskin di dalam suatu masyarakat. Kemiskinan subjekif dirumuskan oleh perasaan kelompok manusia itu sendiri.

Persistensi poverty adalah kemiskinan yang kronis atau berlangsung turun-temurun. Cyclical poverty adalah kemiskinan yang mengikuti siklus ekonomi secara keseluruhan. Seasonal poverty adalah kemiskinan musiman seperti kasus nelayan dan petani tanaman pangan. Accidental poverty adalah kemiskinan karena bencana alam atau karena dampak suatu kebijaksanaan, sehingga kesejahteraan masyarakat menurun.

Kemiskinan alamiah disebabkan oleh kritisnya sumber daya yang dimiliki, terisolasinya wilayah, dan rendahnya kualitas sumber daya manusia. Kondisi inilah yang dapat melahirkan persistent poverty. Kemiskinan kultural disebabkan oleh gaya hidup, kebiasaan hidup, dan budaya yang ada di masyarakat. Mereka merasa kecukupan walaupun pendapatan mereka rendah menurut ukuran yang umum dipakai. Mereka sulit diajak berpartisipasi dalam pembangunan dan kurang tergerak untuk meningkatkan taraf hidupnya. Hal ini sangat berkaitan dengan konsep kemiskinan subjektif. Kemiskinan struktural disebabkan oleh adanya: (1) ketimpangan struktural perekonomian: pembangunan timpang, pemilik sumberdaya tidak merata, kemampuan masyarakat sangat timpang, dan peluang berusaha tidak seimbang; (2) konversi penggunaan lahan dari pertanian kepenggunaan non-pertanian; (3) pengintroduksian teknologi yang bersifat padat modal.

\section{METODE}

Populasi dalam penelitian ini adalah masyarakat/penduduk pesisir Kabupaten Buton, dengan jumlah populasi 340 orang (Tabel 1). Penarikan sampel dilakukan secara proposional sampling. Masing-masing diambil secara acak sederhana karena kondisi masing-masing sampel relatif sama. Jumlah sampel dalam penelitian ini adalah 98 orang. Selanjutnya jumlah sampel didistribusikan ke semua lokasi secara proposional, sehingga diperoleh distribusi sampel sebagaimana pada Tabel 1.

Tabel 1 Distribusi Unit Sampel pada Wilayah Penelitian

\begin{tabular}{cccc}
\hline \multirow{3}{*}{ Kabupaten } & Nama Kecamatan & Jumlah Populasi & Jumlah Sampel \\
\cline { 2 - 4 } Buton & Mawasangka & 102 & 25 \\
& Wabula & 121 & 38 \\
& Sampolawa & 117 & 35 \\
\hline & Jumlah & 340 & 98 \\
\hline
\end{tabular}

Metode pengumpulan data dilakukan dengan cara sebagai berikut. Wawancara dilakukan kepada masyarakat (responden) penerima program bantuan. Kuesioner menggunakan alat bantu berupa pertanyaan-pertanyaan yang ditujukan kepada responden. Dokumentasi dilakukan dengan mengambil data yang telah didokumentasikan oleh instansi terkait yang dilakukan dengan cara mencatat dan fotokopi. Sesuai dengan rumusan masalah dan tujuan penelitian, maka analisis yang digunakan dalam penelitian yaitu tehnik analisis deskriptif kualitatif. 


\section{HASIL DAN PEMBAHASAN}

Pemecahan masalah kemiskinan memerlukan usaha menghilangkan tradisionalisme, fatalisme, karakter cepat puas dan ketidakberanian mengambil risiko. Konsekuensinya adalah diperlukan usaha penataran, pelatihan, ceramah, penyuluhan, dan program khusus seperti Inpres Desa Tertingal (IDT). Untuk menanggulangi kemiskinan secara garis besar di kenal dua pendekatan yaitu, kebijaksanaan yang bersifat tidak langsung dan bersifat langsung. Pendekatan pertama melalui pembangunan ekonami nasional yang berorientasi pasar yang sehat di tingkat petani/nelayan. Pendekatan yang kedua dapat berupa atau terkait dengan program pemerintah secara sektoral seperti pendidikan, kesehatan, prasarana, dan bentuk bantuan langsung pada kelompok miskin. Di satu sisi model penanggulangan kemiskinan memperkuat lembaga-lembaga ekonomi masyarakat di tingkat desa/kelurahan dengan menetapkan koperasi serba usaha dan warung-warung atau kios-kios serba ada. Di daerah penelitian model penanggulangan kemiskinan dengan pendekatan pemberdayaan ekonomi keluarga dan program pendampingan atau bantuan modal usaha, antara lain bantuan sarana produksi untuk nelayan yakni perahu, karamba, kantiting, untuk usaha lain adalah bantuan ternak kambing ternak ayam dan mesin pengering. Model pemberdayaan masyarakat di daerah penelitian adalah melalui pemberdayaan sarana ekonomi antara lain adalah modal usaha nelayan tradisional.

Berdasarkan Tabel 2 besar model pemberdayaan masyarakat dengan pendekatan pemberdayaan ekonomi keluarga dari 12 responden berhasil 10 responden atau 83,33\% dalam peningkatan pendapatan keluarga dan tidak berhasil sebesar 16,67\%. Sementara pemberdayaan usaha produktif petani tradisional dari 46 responden yaitu 36 responden atau 78, 26\% berhasil meningkatkan pendapatan rumah tangga petani dan $21,74 \%$ belum dapat meningkatkan pendapatan rumah tangga petani. Hal ini disebabkan etos kerja serta jiwa kewirausahaan yang dimiliki oleh responden masih lemah.

Tabel 2 Model Pemberdayan Masyarakat Daerah Penelitian Tahun 2013

\begin{tabular}{|c|c|c|c|}
\hline Model & Responden & Berhasil (\%) & Tidak Berhasil (\%) \\
\hline Pemberdayaan Ekonomi Produktif usaha dagang & 12 & $10(83,33)$ & $2(16,67)$ \\
\hline Pemberdayaan Usaha Produktif Petani tradisional & 46 & $36(78,26)$ & $10(21,74)$ \\
\hline Pemberdayaan Modal Usaha Nelayan tradisional & 40 & $22(55,00)$ & $18(45,00)$ \\
\hline Jumlah & 98 & & \\
\hline
\end{tabular}

Di satu sisi, pemberdayaan ekonomi juga sangat ditentukan oleh jenis usaha dan fasilitas usaha yang dimiliki oleh responden. Sementara pendekatan pendampingan banyak dilakukan oleh responden dengan kegiatan usaha nelayan dan pengelola hasil-hasil perikanan sehingga tingkat keberhasilan sebesar 55\% dan tidak berhasil 45\%. Hal ini disebabkan usaha nelayan sangat ditentukan oleh iklim atau cuaca untuk berproduksi. Di samping itu, usaha nelayan dengan modal pendampingan tidak membutuhkan fasilitas usaha yang memadai, cukup hanya bagaimana nelayan dapat meningkatkan produksi, dengan pendampingan nelayan memperoleh sarana/ alat produksi serta metode pengolahan hasil produksi. Menurut Pangemanan (2002), untuk mendukung program pengelolaan dana yang dihibahkan, penduduk menentukan usahanya melalui kelompok-kelompok. Dengan model seperti ini, maka penduduk miskin merasa meraih kemanusian, sehingga mereka bertanggung jawab atas pengelolaan dana. Dengan demikian pemberdayaan ekonomi dapat meningkatkan kesejahteraan masyarakat.

Selain itu, model pendampingan kelompok miskin mutlak dilakukan dalam memperbaiki budaya usaha, memotivasi keluarga dalam pengelolaan keuangan. Pemberdayaan masyarakat dengan pengembangan sumber ekonomi, peningkatan kapasitas masyarakat, dan kelembagaan. Di samping itu 
kegiatan ekonomi di wilayah pesisir didukung dengan mengatur sistem pasar dan manajemen pengelolaan sumberdaya perairan dan pantai.

\section{Penyebab Kemiskinan di Daerah Penelitian}

Karakteristik penduduk miskin di daerah penelitian berkaitan dengan stuktur mata pencaharian. Kurang lebih 90 persen penduduk di daerah penelitian bermata pencaharian sebagai nelayan tradisional. Pekerjaan nelayan sangat ditentukan oleh faktor iklim. Cuaca bersahabat merupakan kesempatan yang berharga untuk melaut atau mencari ikan. Namun jika cuaca tidak bersahabat, tentu kerugian yang paling besar bagi nelayan. Mubyarto (1996) mengemukakan bahwa pekerjaan nelayan adalah pekerjaan yang rentan dengan kemiskinan. Di sisi lain kemiskinan nelayan adalah keterbatasan sarana produksi yang dimiliki dan masih tradisional.

Kemiskinan yang terjadi dewasa ini disebabkan ketidakmampuan untuk memenuhi standar hidup minimum. Ada beberapa penyebab kemiskinan di daerah penelitian.

\section{Rendahnya Tingkat Pendidikan}

Rendahnya kapasitas masyarakat mengelola sumber daya pembangunan, sehingga produktivitas rendah. Hal ini bersumber dari rendahnya tingkat pendidikan masyarakat. Dilihat dari segi pendidikan responden di daerah pendidikan yang relatif rendah. Dari 98 responden, sekitar $57.33 \%$ di daerah penelitian masih di bawah pendidikan dasar sembilan tahun. Di satu pihak, rendahnya pendidikan akan sulit memperoleh pekerjaan yang produktif di luar usaha nelayan. Penduduk dengan pendidikan relatif rendah akan berpengaruh terhadap produktivitas, pada gilirannya pembentukan model rendah. Hasil penelitian Rahmat (1996) mengemukakan bahwa masyarakat dengan tingkat pendidikan dasar $62.5 \%$ adalah masyarakat dengan tingkat produktivitas rendah, dan pada gilirannya pendapatan petani rendah. Sementara penduduk masyarakat yang bermata pencaharian nelayan, petani, dan usaha kecil lainnya $64 \%$ dengan pendapatan rata-rata per musim sebesar Rp.2.500.000,-. Indikasi ini menunjukkan bahwa tingkat pendidikan masyarakat berkorelasi dengan tingkat pendapatan. Makin tinggi pendidikan formal nelayan/petani, maka makin tinggi untuk melakukan transformasi struktural ke luar sektor pertanian. Di satu pihak transformasi struktur ke sektor non-pertanian dapat mengentaskan kemiskinan penduduk di daerah pedesaan dengan model pengembangan sumber daya manusia.

\section{Kurangnya Permodalan}

Sumber-sumber modal untuk pengembangan usaha di daerah penelitian sangat terbatas. Hal ini disebabkan terbatasnya pemilikan faktor produksi antara penguasaan lahan (tanah) tidak ada. Modal usaha adalah dalam arti uang/dana yang dimiliki oleh responden di daerah penelitian dapat dilihat pada Tabel 3 .

Tabel 3 Modal Usaha Responden Daerah Penelitian

\begin{tabular}{clcc}
\hline \multirow{2}{*}{ No } & \multirow{2}{*}{ Interval Modal (Rp) } & \multicolumn{2}{c}{ Frekunsi } \\
\cline { 3 - 4 } & & Orang & \% \\
\hline 1. & $5.000 .000-10.000 .000$ & 47 & 4796 \\
2. & $11.000 .000-20.000 .000$ & 35 & 35,71 \\
3. & $>21.000 .000,-$ & 16 & 16,33 \\
\hline & Jumlah & 98 & 100 \\
\hline
\end{tabular}


Mengamati permodalan masyarakat di dalam penelitian sebagai responden data yang diperoleh menunjukan bahwa modal usaha berkisar Rp. 500.000,- sampai dengan Rp. 10.000.000,adalah 47 orang atau 47,96 persen dan masyarakat yang modal usahanya diatas Rp. 21.000.000,hanya 16 orang keadaan ini menunjukkan bahwa masyarakat di daerah penelitian dalam mengembangkan usahanya masih terkendala modal pada gilirannya akan berpengaruh terhadap pendapatan.

Di sisi lain dengan minimnya modal yang dimiliki oleh masyarakat untuk kegiatan ekonomi produktif maka realokasi modal kurang efisien. Di samping itu mobilisasi uang atau modal didaerah penelitian sangat lambat yang pada gilirannya daya beli masyarakat rendah, Hidayatullah (2007) mengemukakan bahwa modal usaha untuk pemberdayaan ekonomi masyarakat sebesar Rp. 30.000.000,- sampai dengan Rp. 50.000.000,-, dengan demikian maka modal usaha responden di daerah penelitian masih kurang atau dengan kata lain pemberdayaan ekonomi masyarakat miskin didaerah penelitian belum maksimal.

\section{Jenis Pekerjaan Responden}

Penyebab kemiskinan di daerah penelitian salah satunya adalah jenis pekerjaan. jumlah responden yang diamati sebanyak 68 orang $(96,67 \%)$ menggeluti pekerjaan sebagai nelayan tangkap dan sisanya $3,33 \%$ usaha lain.

Tabel 4 Jenis Pekerjaan Utama

\begin{tabular}{llcc}
\hline \multirow{2}{*}{ No } & \multirow{2}{*}{ Jenis Pekerjaan } & \multicolumn{2}{c}{ Frekuensi } \\
\cline { 3 - 4 } & & Orang & \% \\
\hline 1. & Nelayan/tani & 68 & 96,67 \\
2. & Usaha lainnya & 30 & 3,33 \\
\hline & Jumlah & 98 & 100 \\
\hline
\end{tabular}

Tabel 4 memperlihatkan bahwa jenis pekerjaan responden di daerah penelitian masih dalam kegiatan usaha mikro yang tingkat produktivitasnya rendah yaitu jenis pekerjaan nelayan adalah pekerjaan yang berisiko tinggi dalam pengelolaan usahanya Mubyarto (1996), berpendapat bahwa nelayan dengan alat tangkap sederhana sangat rentang dengan lingkaran kemiskinan. Hal ini oleh karena pekerjaan nelayan sangat tergantung pada keadaan cuaca (ombak) dilaut atau dengan kata lain kemiskinan nelayan disebabkan oleh karena kehidupan mereka tergantung pada faktor alam, jika musim baik maka mereka akan hidup dengan baik, dan jika musim tidak akrab maka akan merugi dan tidak berbuat apa-apa sehingga hidup tak tentu. Leokman (1987) menjelaskan bahwa nelayan tradisional dengan kehidupan tergantung kepada perairan laut, yang faktor cuaca memengaruhi hasil tangkapan atau hasil produksi ikan. Hal ini apabila cuaca baik maka hasil tangkapan akan meningkat, sebaliknya cuaca buruk akan tidak melaut.

Di samping itu jenis pekerjaan sebagai petani dengan luas areal garapan kurang lebih 0,5 ha, akan memengaruhi tingkat produktivitas pada gilirannya memengaruhi pendapatannya. Di daerah penelitian rata-rata responden memiliki luas areal untuk tani kurang lebih 0.5 ha hal ini mengindikasikan bahwa petani di daerah penelitian masih petani gurem. Menurut Mubyarto (1996) usaha tani dengan luas garapan kurang lebih satu hektar tergolong petani miskin dan produktivitasnya rendah. Di sisi lain usaha tani memiliki produktivitas dan pendapatan yang tidak menentu karena banyak faktor yang memengaruhinya antara lain, musin, harga komoditas dan sifat komditinya cepat rusak. 


\section{Fasilitas Usaha}

Penyebab kemiskinan di daerah penelitian adalah kurangnya fasilitas usaha. Hal ini antara lain tempat usaha, alat produksi dan fasilitas-fasilitas lain yang berkaitan dengan usaha responden.

Tabel 5 Fasilitas Usaha Responden di Daerah Penelitian Tahun 2013

\begin{tabular}{llcc}
\hline \multirow{2}{*}{ No } & \multirow{2}{*}{ Fasilitas Usaha } & \multicolumn{2}{c}{ Frekuensi } \\
\cline { 3 - 4 } & & Orang & \% \\
\hline 1. & Gerobak & 25 & 25,51 \\
2. & Kios ( Tempat Jualan) & 19 & 19,39 \\
3. & Tidak ada & 54 & 55,10 \\
\hline & & 98 & 100 \\
\hline
\end{tabular}

Tabel 5 memperlihatkan bahwa fasilitas usaha yang dimiliki oleh responden di daerah penelitian tergolong sangat minim yaitu hanya 25 responden yang memiliki fasilitas gerobak dan 19 reponden memiliki fasilitas kios atau warung sembako sementara 54 reponden tidak memiliki fasilitas usaha atau tidak mempunyai kegiatan tempat untuk kegiatan ekonomi produktif. Hal ini menunjukan bahwa responden (masyarakat) di wilayah penlitian belum dapat melakukan transaksi produksi secara efisien. Menurut Elfindri (2002), untuk meningkatkan transaksi pasar secara efisien harus tersedia tempat atau fasilitas yang baik untuk penjualan dan pembeli sehingga aliran uang dapat beredar efisien.

Di satu sisi fasilitas usaha atau tempat untuk usaha mikro dan kecil sangat diperlukan untuk mempromosikan produksi atau barang yang dihasilkan oleh masyarakat, khususnya tangkapan nelayan. Dengan demikian fasilitas usaha sangat berkaitan dengan tingkat produktivitas. Atau dengan kata lain tempat usaha merupakan sarana untuk memperoleh aliran modal usaha dari pemilik modal.

\section{Tingkat Pendapatan}

Pendapatan masyarakat wilayah pesisir adalah salah satu karakteristik yang dapat membedakan lapisan masyarakat di pedesaan sementara pendapatan bersih masyarakat (responden) adalah nilai produksi yang dijumlahkan dalam satu tahun setelah dikurangi dengan biaya-biaya. Pendapatan masyarakat wilayah pesisir bersumber dari hasil usaha penangkapan ikan, usaha dagang, usaha produktif lain dan pendapatan lain yang berkaitan dengan kegiatan masyarakat wilayah pesisir.

Tabel 6 Tingkat Pendapatan Responden di Daerah Penelitian

\begin{tabular}{cccc}
\hline \multirow{2}{*}{ No } & Interval & \multicolumn{2}{c}{ Frekuensi } \\
\cline { 3 - 4 } & & Orang & \% \\
\hline 1. & $1.000 .000-2.000 .000$ & 25 & 25,51 \\
2. & $2.100 .000-5,000.000$ & 49 & 55.06 \\
3. & $\geq 5$ juta & 14 & 14,29 \\
\hline & & 98 & 100 \\
\hline
\end{tabular}

Tabel 6 memperlihatkan bahwa pendapatan responden di daerah penelitian dalam satu musim adalah interval antara Rp1.000.000,- sampai dengan Rp2.000.000,- sebanyak 25 orang atau 25,51\%; sementara pendapatan antara Rp2.100.000,- sampai dengan Rp5.000.000,- sebanyak 49 responden 
atau 55,06\%. Hal ini menunjukkan bahwa pendapatan masyarakat wilayah pesisir masih di bawah rata-rata $\mathrm{Rp} 3000.000$ atau dengan kata lain bahwa pendapatan masih rendah. Di satu pihak rendahnya pendapatan akan berpengaruh terhadap tabungan dan pada gilirannya pembentukan modal rendah.

\section{SIMPULAN}

Berdasarkan hasil penelitian yang telah diuraikan, maka dapat disimpulkan bahwa model pemberdayaan masyarakat di wilayah pesisir di Kabupaten Buton adalah pemberdayaan ekonomi keluarga dari 12 responden berhasil 10 responden atau 83,33\% dalam peningkatan pendapatan keluarga dan tidak berhasil sebesar $16,67 \%$. Model pemberdayaan usaha produktif petani tradisional dari 46 responden yaitu 36 responden atau 78,26\% berhasil meningkatkan pendapatan rumah tangga petani dan $21,74 \%$ belum dapat meningkatkan pendapatan rumah tangga petani. Hal ini disebabkan etos kerja serta jiwa kewirausahaan yang dimiliki oleh responden masih lemah. Di satu sisi pemberdayaan ekonomi juga sangat ditentukan oleh jenis usaha dan fasilitas usaha yang dimiliki oleh responden, sementara pendekatan pendampingan banyak dilakukan oleh responden dengan kegiatan usaha nelayan dan pengelola hasil-hasil perikanan sehingga tingkat keberhasilan sebesar $55 \%$ dan tidak berhasil $45 \%$. Hal ini disebabkan usaha nelayan sangat ditentukan iklim atau cuaca untuk berproduksi. Di samping itu usaha nelayan dengan modal pendampingan tidak membutuhkan fasilitas usaha yang memadai, cukup hanya bagaimana nelayan dapat meningkatkan produksi, dengan pendampingan nelayan memperoleh sarana/ alat produksi serta metode pengolahan hasil produksi. Oleh kerena itu penanggulangan kemiskinan dengan sasaran nelayan/petani tidak cukup dengan pemberdayaan ekonomi.

\section{DAFTAR PUSTAKA}

Abibu, U. (2007). Analisis Penanggulangan Kemiskinan Melalui Program Pengembnagan Kecamatan (PPK) di Kabupaten Konawe. Tesis. Program Studi Ilmu Ekonomi dan Studi Pembangunan Program Pascasarjana Universitas Haluoleo. Kendari.

Badan Pusat Statistik (BPS). (2012). Kabupaten Buton Dalam Angka. Badan Pusat Statistik Kabupaten Buton.

Cook, S., \& Macaulay, S. (1997). Practical steps to empowered complaint management. Managing Service Quality: An International Journal, 7(1), 39-42.

Elfindri. (2002). Ekonomi Patron-Klien. Fenomena Mikro Rumah Tangga Nelayan dan Kebijakan Makro. Padang: Universitas Andalas.

Huda, N. (2005). Dampak Pemberian Kredit Mikro terhadap pendapatan Masyarakat perdesaan melalui Lembaga Simpan Pinjam Berbasis Masyarakat dari Program Pemberdayan Masyarakat (CERD) di Kecamatan Aluh-Aluh Kabupaten Banjar. Tesis Program Studi Ilmu Ekonomi Program Pascasarjana Universitas Gadjah Mada Yogyakarta.

Kartasasmita, G. (1996). Pembangunan Untuk Rakyat: Memadukan Pertumbuhan dan Pemerataan. Jakarta: Pustaka Cidesindo.

Mubyarto. (1996). Strategi pembangunan masyarakat desa di Indonesia. Aditya Media. 
Nasution, L. I. (1996). Taksonomi Kemiskinan di Indonesia. Jakarta: Grasindo.

Pangemanan, A. P. (2002). Sumberdaya Manusia (SOM) Masyarakat Nelayan. W NW rudict tripod com, 22.

Prayitno, H. \& Santosa, B. (1996). Ekonomi Pembangunan. Jakarta: Ghalia Indonesia.

Prijono \& Pranarka. (1996). Pemberdayaan Konsep dan Implementasi. Jakarta: CSIS.

Soetrisno, S. (1996). Impacts of urban and industrial development on groundwater, Bandung, West Java, Indonesia. In Symposium on Groundwater and Landuse Planning, Fremantle, Western Australia, 16-18 September 1996.

White, B. (1996). Dalam Sitorus, M.T.F., Agus, Titik Sumarti, dan Gunadi (Penyunting). Memahami dan menanggulangi kemiskinan di Indonesia. Jakarta: Grasindo. 